\title{
Pursuing Joy with Deleuze: Transcendental Empiricism and Affirmative Naturalism as Worldly Practice
}

Conor Heaney, University of Kent, Canterbury

\begin{abstract}
In this paper, I seek to extract what I call an empiricist mode of existence through a combined reading two under-researched vectors of Gilles Deleuze's thought: his 'transcendental empiricism' and his 'affirmative naturalism'. This empiricist mode of existence co-positions Deleuze's empiricism and naturalism as pertaining to a stylistics of life which is ontologically experimentalist, epistemologically open, and immanently engaged in the world. That is, a processual praxis of demystification and organising encounters towards joy.
\end{abstract}

Keywords: transcendental empiricism, naturalism, affirmation, encounter, mode of existence, joy

In this paper, I seek to extract what I call an empiricist mode of existence through a combined reading two under-researched vectors of Gilles Deleuze's thought: his 'transcendental empiricism' and 'affirmative naturalism'. This empiricist mode of existence co-positions Deleuze's empiricism and naturalism as pertaining to a stylistics of life which is ontologically experimentalist, epistemologically open, and immanently engaged in the world. That is, a processual praxis of endowment for signs and demystification organised towards joy. It seeks to cultivate joy through an affirmative (and demystifying) approach to encounters. I follow Deleuze in situating encounters as those affectively disturbing and transformative experiences which puzzle and shake us, forcing us to think. To my knowledge, a combinative reading of Deleuze's transcendental empiricism and affirmative naturalism has not yet been attempted.

Ultimately, the purpose of this paper is three-fold. First, I seek to contribute to the research on Deleuze's empiricism and naturalism, both of which are under-explored and which, I argue, can be instructively considered in tandem. Second, I wish to build 
upon the relatively new and growing body of research on what Deleuze's work might have to say in relation to the development of a specifically Deleuzian philosophy of life or aesthetics of existence, and thereby to argue that Deleuze's empiricism and naturalism are indissociable from wordly practice, and cannot be reduced to methodology or philosophical practice. Thirdly, I hope that this research can generate new problems, new venues of exploration, experimentation, research, and practice; I will gesture towards some such problems in the conclusion.

In the first section of this paper, I will briefly outline the contours of transcendental empiricism. In the second section, my attention will turn to affirmative naturalism. The third section will develop from these, extracting and developing the combinative reading of these two positions I am calling an empiricist mode of existence. I conclude in the final section with gestures towards the new problematics this paper generates.

\section{Transcendental Empiricism}

The seemingly oxymoronic term transcendental empiricism is one that Deleuze affirms both in relatively early works (notably Difference and Repetition) and later ones (namely, Immanence: A Life (Deleuze 20o1: 25)). As James Williams notes, the term itself has received relatively little independent attention in the literature on Deleuze (Williams 2010: 115). In order to detach Deleuze's transcendental empiricism from his various gestures towards it, I will first distinguish Deleuze's singular approach to empiricism which is, unsurprisingly, not a classically epistemological one. Second, I will then reanimate Deleuze's famous philosophical rallying call against the Image of Thought in chapter three of Difference and Repetition as a rallying call (i) against conceptual 
approaches which presuppose the nature, trajectory, and ends of sensibility and thought (uncritical ontologies of sensibility and thought) and (ii) towards conceptual approaches which interrogate the genesis of sensibility and thought as such. In pursuing these two tasks, transcendental empiricism becomes, I argue, a continuous philosophical and wordly practice which confronts, affirms, and differentially actualises the conditions of genesis of sensibility and thought. I will now turn to the first of these two tasks: situating Deleuze's empiricism.

One of the initial issues that arise with Deleuze's characterisation of his approach as a type of empiricism is the considerable historical-philosophical baggage such a term comes with, potentially, of course, inviting associations with the empiricisms of Francis Bacon, John Locke, George Berkeley, David Hume, and so forth. ${ }^{1}$ Empiricism, in this 'classic' guise, is described by Deleuze (following Kant) in Empiricism and Subjectivity as such: 'empiricism is the theory according to which knowledge not only begins with experience but is derived from it' (Deleuze 1991: 107). In other words, such empiricism is about the subject's experiential and processual acquisition of epistemological closure. It is epistemological in the sense that it is focused on how the subject acquires knowledge about the natural world from the zero-point of its experience of it. It proceeds from a certain type of ontological starting point ('the subject who experiences and thinks') and asks how might such a subject acquire knowledge about the natural world. Experience functions as an epistemic ground for the subject of classical empiricism: sensible experience is, here, the explanans, and the 'subject who experiences' is presupposed, or is the very starting point. Furthermore, such an empiricism presupposes that the proper object and application of thought is the attainment of 'knowledge.' In this sense, such an empiricism is epistemologically 
unidirectional. Succinctly put, epistemological empiricism both presupposes a certain given point of departure ('the subject who experiences and thinks') and a proper point of arrival ('knowledge') as the proper movement or process of thought. This combination of a point of departure and point of arrival is empiricism's ontology of thought.

Such epistemological unidirectionality is a far cry from what Deleuze takes to be the 'object' or problem of his empiricism, which is concerned not with how we might acquire knowledge from the starting from of an experiencing and thinking subject, but instead with transcendental conditions of experience and thought themselves. In other words, whereas epistemological empiricism takes thought and experience as ontologically given, Deleuze pivots the object of empiricism towards an investigation of how the given, experience, and thought is produced; not assuming, and thereby investigating the production of the given is one of the tasks of a Deleuzian empiricism (Bryant 2008: 11). In this sense, Deleuze treats as an explanandum what epistemological empiricism treats as an explanans. Further, insofar as Deleuze's seeks to push the problem empiricism confronts towards that of the production of the given, Deleuze's empiricism thereby becomes focused on the creative and speculative exploration of ontological processes rather than the search for epistemological closure. In Kantian parlance, Deleuze is not concerned with the conditions of possibility of knowledge, but with the transcendental conditions of thought and experience (Beistegui 2010: 15). In this way, Deleuze will not assume the nature, possible trajectories, or targeted ends of thought, nor he will not take the operation of thought for granted. Succinctly put, Deleuze's transcendental empiricism has a very different point of departure ('what are the transcendental conditions of experience and thought?') and no obvious proper point of arrival (insofar as it does not assume the nature, trajectory or ends of thought's 
movement) when compared to its epistemological namesake. Whereas epistemological empiricism presupposes a thinking and experiencing subject as a point of departure, Deleuze's transcendental empiricism actively questions what produces thought and experience and so shifts the point of departure to questions of ontological processes and processes of individuation (that of the ontogenesis (Simondon 2009) of experience and thought); and where epistemological empiricism presupposes a certain movement of thought with a unidirectional point of arrival ('knowledge' or 'epistemological closure'), Deleuze's transcendental empiricism will actively develop and offer an alternative ontology of thought. As Miguel de Beistegui puts it:

The transcendental in Deleuze's sense amounts to a double twisting free, therefore: first, of transcendence, whether as God, being, or consciousness; second, of the problematic regarding the conditions of possibility of experience and knowing in general, irreducibly complicit with the logic of resemblance. Instead, Deleuze privileges the standpoint of immanence and the problematic of genesis: transcendental empiricism is concerned with isolating the genetic and immanent conditions of existence of the real. (Beistegui 2010: 15)

Of course, the ontological presuppositions of empiricism's ontology of thought are by no means presuppositions tied solely to the varieties of epistemological empiricism of Locke, Hume, and so forth. Rather, they are manifestations of the 'subjective presuppositions' which Deleuze famously claims permeate much of the Western philosophical tradition. Writing specifically on Descartes, Hegel and Heidegger (as exemplars rather than mere examples), Deleuze claims that they refuse 'objective presuppositions, but on condition of assuming just as many subjective presuppositions' (Deleuze 2014: 171) about the nature, trajectory and ends of thought. These 'subjective 
presuppositions' - the 'I think' for Descartes, the 'concrete empirical being' for Hegel, 'pre-ontological understanding' for Heidegger - take as a starting point or explanans what Deleuze treats as the explanandum. Deleuze calls the ontology of thought which structures these presuppositions, of course, the Image of Thought. I will not here recapitulate the various presuppositions - what Deleuze calls the eight 'postulates' - of this Image of Thought. However, it will be useful for my purposes to develop in a little more detail the functionality or effects the Image of Thought has. For Deleuze, an image of thought acts both as the pre-philosophical impetus for where and how thought begins and also as that which constitutes thought's end; as I noted above, it is an ontology of thought with an in-built point of departure and point of arrival. In this way, an image of thought 'surrounds' thinking. It constitutes a 'pre-philosophical understanding of what it means to think' (Beistegui, 2010: 9) and is both an initiative and orientative function of thought's movement. To continue the example from above which Deleuze uses: in Descartes, what it means to think is to strip away objective presuppositions and proceed from the indubitable 'I think.' This both enables thought for Descartes (this is the image's initiative function) but also constrains it insofar as Descartes will be disabled from considering, for example, the transcendental question of thought's possibility in the first place in virtue of its point of initiation, which assumes it. An image of thought is a usually un-thought origin of thought which both structures and constrains thought's purposive 'end-point.'

Nonetheless, a crucial point worth highlighting at this point is the sense in which Deleuze's criticisms of the Image of Thought are not criticisms which denigrate the task of grounding one's claims (or grounding philosophical practice more generally), or ones which seek to dispense with the philosophical importance of such a task, especially 
insofar as such a task traverses Deleuze's oeuvre. In 1956-57, for example, Deleuze gave a seminar entitled What is Grounding? In this seminar series, Deleuze notes that the problem of grounding appears whenever one goes 'beyond the given,' as, indeed, with all 'knowing' as such. Discussing Hume, for example, Deleuze asks: 'when do we appeal to a ground? When one no longer relates one's activity to himself as an agent [...] It is the subject who goes beyond, who evokes the problem of the ground' (Deleuze 2015: 2526). Further, towards the end of his life, with Guattari, Deleuze revisits the question of grounding in What is Philosophy?; here, philosophy is famously positioned as a constructivist practice of concept creation in which grounding is an indissociable part (Deleuze and Guattari 2013b: 77). Or more precisely, concept creation, for Deleuze and Guattari, will necessitate the institution of a pre-conceptual plane (a ground) which enables thought's orientation or practice. All philosophical practice, for Deleuze, incorporates this institution of a ground, or a practice of grounding, which enables thought to be pursued (whether or not this ground is explicitly theorised is, of course, a separate question):

This image is what indicates, always indirectly, obliquely, what it means to think, to use thought, to orient oneself in thought [...] The image of thought is a plan in that sense: it provides a thought with its fundamental direction and its general climate; it orients and channels it. (Beistegui 2010: 10-11).

The issues, therefore, that Deleuze identifies through the eight postulates is not so much that these postulates seek to ground, but that they are not critical enough in their very practices of grounding. More specifically, Deleuze will charge the Image of Thought with a non-immanent practice of tracing the transcendental from the empirical, that is, 
a circular practice of grounding. In the 'search' for a ground for thought, tracing the transcendental from the empirical involves the practice of grounding thought in resemblance to, or in the image of, the empirical. So, for example, in Descartes's cogito, thought is provided with a 'stable ground' upon which reason can attain epistemological closure (secure points of departure and arrival). Insofar as consciousness is instituted as this ground it is, for Deleuze, tracing the transcendental from the empirical; or quite simply doubling the empirical in a vicious circle in which the transcendental is conceived of in resemblance to that which it is supposed to ground. As Levi Bryant notes (2008: 36), this risks essentialising the empirical and singular as a transcendent ground of thought. Deleuze wrote forcefully on this in The Logic of Sense:

The error of all efforts to determine the transcendental as consciousness is that they think of the transcendental in the image of, and in the resemblance to, that which it is supposed to ground [...] [This] vicious circle makes the condition refer to the conditioned as it reproduces its image [...] What is common to metaphysics and transcendental philosophy is, above all, this alternative which they impose on us: either an undifferentiated ground, or groundlessness, formless nonbeing, or an abyss without difference and without properties, or a supremely individuated Being and intensely personalized Form. Without this Being or this Form, you will have only chaos. (Deleuze 2013: 9)

Indeed, Deleuze's precise criticism of such points of departure, and such tracing practices, is that they do not live up to their putative criticality. As Bryant reiterates, Deleuze's criticises these canonical figures (for example, Descartes, Hegel, Heidegger) in the Western philosophical tradition 'not because he is rejecting the notion of critique, of having to ground one's claims, but rather because these positions are not critical 
enough' (2008: 16). Deleuze's outlining of the eight postulates of the Image of Thought functions as a set of criticisms of the absorption and reproduction of an uncritical ontology of thought and as an incitement of what he sees as the critical question - the transcendental question which his empiricism is concerned with - of what produces experience and thought at all.

Having outlined this, I will now turn to some of Deleuze's more 'positive' responses to the questions which he sees as being largely elided in the Western philosophical tradition. In response to the question, the transcendental question, of what produces experience and thought in the first place, Deleuze instead forcefully suggests that thought is forced into being as the result of a fundamental encounter. What might this mean? Thought - rather than being its own condition, initiator and ground - is positioned by Deleuze as being produced as a result of an exogenetic (Beistegui 2010: 13-15) and ontological 'event' he terms 'the encounter.' More specifically, Deleuze's claim is that thought's genesis is to be found in an encounter with that which 'can only be sensed' (the sentiendum or the 'being of the sensible') (Deleuze 2014: 183). In other words, rather than being related to what is recognisable, thought is produced when we encounter that which we precisely do not recognise; the object of the encounter 'is imperceptible precisely from the point of view of recognition' (Ibid. 184). Experience and thought are produced in an encounter with that which can only be sensed - that which can only be felt - rather than that which can be recognised, represented, or known. The encounter is undoubtedly empirical and immanent to experience, but nonetheless exogenetic, the 'object' of the encounter is treated by Deleuze as a transcendental sign; which, of course, is to say as a condition for thought, and not a transcendent (or supernatural) sign. The transcendental sign of the encounter functions 
as a potential condition for the movement of learning, as Benoît Dillet notes: 'learning how to think concerns signs, and compares the thinker to an Egyptologist trying to decipher hieroglyphs and signs, to give them sense and value. Faculties can only be discordant once they are disturbed by external signs' (Dillet 2013: 257). ${ }^{2}$

In other words, the encounter with that which can only be sensed does not presuppose the exercise of the subject's faculties of thought - it is not presupposing the 'subject who experiences and thinks' - instead, an encounter with the sentiendum here refers to an encounter which produces sensibility itself: 'The object of the encounter [...] really gives rise to sensibility with regard to a given sense [...] It is not a sensible being but the being of the sensible' (Deleuze 2014: 184). And which, further, forces thought into being, forcing thought 'to pose a problem: as though the object of encounter, the sign, were the bearer of a problem' (Ibid. 184). Thought is not simply the exercise of a naturally pre-endowed faculty, but must be excited into being (Rölli 2016: 160; also see Abdullah 2016:30). The encounter with the sentiendum ignites thought precisely insofar as the sentiendum cannot be grasped, recognised, or understood. Deleuze calls this movement from the encounter to the posing of a problem the movement between an encounter with the being of the sensible (the sentiendum) to the thinking of the being of the intelligible (the cogitatum). He describes similar movements of the faculties in a number of different ways: thinking that which can only to be sensed, perceiving the imperceptible, imagining the unimaginable, speaking silence, and so forth. These movements are Deleuze's descriptions of the experimental pushing of faculties to their limits, a pushing occasioned by the disturbance of encounters with transcendental signs (Deleuze 2014: 188). The shock of these patterns are ones Deleuze describes in violent terms: as a dark precursor, an impersonal trespassing enemy striking us unexpectedly 
(Ibid. 183). As John Rajchmann notes, thought begins 'with the encounter with something that doesn't fit in habitual ways of seeing and thinking, that 'shakes up' thinking and puts up something new to be thought' (Rajchmann 2000: 45). Importantly, against the Image of Thought, which positions thought as a voluntary and selfcontained movement (as when consciousness or the 'subject' is rendered or positioned as transcendent or as transcendental consciousness, and thereby as a firm ground for thought) and as epistemologically unidirectional (as a movement towards knowledge or epistemological closure), Deleuze instead positions thought, through this notion of the encounter, as exogenetic and involuntary, the results of which are unpredictable, differential, and heterogenetic. In short, thought's point of departure is the encounter and its point of arrival cannot be foretold. In this sense, thought's results are not completely reducible to the encounter, and instead are positioned as movements of differential actualisation:

Each faculty, including thought, has only involuntary adventures: involuntary operation remains embedded in the empirical [...] Even the point of departure namely, sensibility in the encounter with that which forces sensation presupposes neither affinity nor predestination. On the contrary, it is the fortuitousness or contingency of the encounter which guarantees the necessity of that which it forces to be thought. (Deleuze 2014: 190-191)

This is Deleuze's alternative to the Image of Thought's tracing of the transcendental from the empirical; instead of conceptualising the transcendental in the image of, or resemblance to, the empirical, the transcendental is instead conceptualised as external to and different from thought. The transcendental is no longer the subject but that which 
produces the subject. Thought is not a 'transcendent exercise of the faculties' geared towards the attainment of epistemological closure, but is rather an effect of encounters with transcendental signs, encounters which ontologically transform the subject of the encounter and can push faculties to their limits (Ibid. 188-189). So, if thought is an involuntary movement, and the results of encounters are unpredictable, my claim here is that Deleuze's transcendental empiricism can be positively and practically defined as both ontologically experimentalist and epistemologically open. It is ontologically experimentalist insofar as it suggests that if we are to think or to learn - if thought is to become an object of practice - we must seek out encounters, be worthy of them, we must seek out our own ontological transformation and push against the limits of our faculties. On this, in a late essay, Deleuze argues that, with Hume, empiricism transforms theory into inquiry: 'Science or theory is an inquiry, which is to say, a practice: a practice of the seemingly fictive world that empiricism describes; a study of the conditions of legitimacy of practices in this empirical world that is in fact our own. The result is a great conversion of theory to practice' (Deleuze 1991: 36). Further, transcendental empiricism is also both ontologically experimentalist and epistemologically open insofar as the results of this seeking out of encounters, of encounters themselves, and of thought remains unknown; 'one cannot prejudge the outcome of research' (Deleuze 2014: 188). It is for this reason that Bryant claims that 'transcendental empiricism is an account of learning rather than an epistemology or an account of coming to know [...] learning assumes a transformation of oneself and how we relate to the world' (Bryant 2008: 149). To make thought an object of practice is, in this way, an opening of oneself to movements of learning, and a process of learning which can itself change the future genetic conditions of experience (Rölli 2016: 280; also 
see Smith 2012: 240). Deleuze's transcendental empiricism is, thus, indissociable from worldly practice, and cannot be reduced to a narrative of the attainment of epistemological closure, or be focused solely on questions of methodology or philosophical practice (also see Rölli 2016: 279-280). Underlining this, Marc Rölli notes how Deleuze's empiricism is not only about those threshold-sensory experiences which force us to think, but is bound up with the differential explication of thought itself, so that 'philosophy becomes involved more deeply in the transcendental regions of experience - instead of skimming over them heavenward in search of immutable essences' (Rölli 2016: 230).

No doubt, this account of thought leans upon Deleuze's virtual-intensive-actual ontology (hence thought's movement of 'differential actualisation') which he develops separately on a number of occasions, and which I do not have sufficient scope in this paper to expound. ${ }^{3}$ It will, however, be pertinent to outline three points on this before moving to the explication of Deleuze' affirmative naturalism in the next section. First, Deleuze suggests that 'the virtual' or 'difference-in-itself' is the precise object of his transcendental or 'superior' empiricism (Deleuze 2014: 71), and that 'difference-in-itself' is that which can push faculties to their limits through this movement of differential actualisation (Ibid. 189). Second, as a process of differential actualisation, thought (as I already noted) is not reducible to the encounter 'itself.' What I wish to subtract from this is the oft-repeated point that, for Deleuze, the field of virtuality is decidedly not a field of 'possibility' which needs only to be fulfilled. Positioning the field of virtuality as a set of pre-constituted possibles would be to embed identity and resemblance into thought's movement. The differential actualisation of thought is, for Deleuze, a process of heterogenesis (Deleuze 2015: 4). Thought, thereby, does not fulfil the possible, but 
differentially actualises the virtual. Thirdly, and relatedly, the heterogenetic movement of thought is, for Deleuze, a temporal movement of ontological transformation and the production of novelty. The transcendental conditions of real experience cannot, for Deleuze, resemble empirical experience, as this would both reinstate the logic of representation and resemblance into the movement of thought and would constitute the 'doubling of the empirical' we noted above. As Daniel Smith notes, Deleuze's genetic method and focus on real experience allows him to account for novelty or 'the new' insofar as the actualisation of thought, or indeed any process of actualisation, constitutes the production of the new (Smith 2012: 240) and is in no sense a fulfilment of the possible. Further, Deleuze's focus on the genetic conditions of thought, the constitutive 'threshold experience' of the encounter, and the positioning of thought as a movement of differential actualisation, enables him to go beyond even Edmund Husserl's genetic phenomenology which, as Rölli notes, remains tied to a conception of sensation and experience of a transcendental consciousness (Rölli 2016: 126). The process of thought is positioned by Deleuze as both a process of differential actualisation, but also as a process through which the 'subject' of the encounter is qualitatively transformed through the encounter and through thought, thought which has been ignited through an empirical encounter with a transcendental sign. These three points serve to highlight that the learning process the encounter can ignite is, of course, not a process of mimesis or the reproduction of a certain proper methodology of thought, but rather involves experimentation and practice; 'to constitute the space of an encounter with the problem and to respond to it, to transform oneself in the process of resolution' (Posteraro, 2015: 466). 
Let me draw together some of the key elements of this section before moving on. I began by noting that Deleuze's transcendental empiricism can be approached first through its criticisms against conceptual approaches which presuppose the nature, trajectory, and ends of sensibility of thought; and further, through Deleuze's own attempts to interrogate and elucidate the transcendental condition of thought which, for him, is the encounter, a puzzling, disturbing, and liminal empirical experience which does not fit into the subject's habitual thought patterns. In effect, and again in a practical sense, transcendental empiricism becomes a constant interrogation into the conditions of genesis of sensibility and thought, which, to say the same thing in different terms, amounts to a continuous praxis of learning. Of course, the involuntariness - or passivity - through which thought is shocked into being appears to conflict with the notion of a praxis - or theoretico-pratical activity - of learning. Indeed, this apparent conflict provides us with a smooth segway into the next two sections, where I will respond to this conflict through an explication of Deleuze's affirmative naturalism, and then through an elucidation of what I am in this paper calling Deleuze's empiricist mode of existence.

\section{Affirmative Naturalism}

If Deleuze's charges the 'Western philosophical tradition' with an uncritical absorption and reproduction of an uncritical ontology of thought, this is nonetheless not a homogeneous charge. It is through the works of, among others, Lucretius, Leibniz, Spinoza, Nietzsche, and Bergson, that Deleuze (differentially) subtracts a reservoir of philosophical potential for overturning the Image of Thought and thinking differently. 
Before moving too quickly, however, I will first connect this section more closely to the trajectory developed thus far.

When faced with the object of the encounter - which Bryant terms a 'transcendental sign' and a 'sign of [...] the genetic factors out of which the diversity of the given is produced' (Bryant 2008: 100) - how might thought respond? Indeed, when confronted with the trauma of the encounter, thought may simply react to or negate the sign through explaining its appearance as an instance of misrecognition, mystification, as a sign of the supernatural, and so forth. All of these are manifestations of thought's tendential stupidity (with Nietzsche, we will address this claim in more detail below). In such cases, thought reproduces the conservatism of the Image of Thought; such a reproduction functions as a negation of the encounter - and a negation of thought itself - insofar as it involves thought's negation of its own transcendental condition. As Williams notes, the encounter with a transcendental sign can be treated as a 'moment of uncertainty providing the opportunity of thinking and acting differently' (Williams 2016: 8). As an opportunity, our response to the encounter is in no sense determined. Can thought affirm this traumatic encounter, especially insofar as encounters are involuntary, fortuitous, and contingent adventures? What might it mean to affirm the encounter rather than simply react to it? If the Image of Thought is a reactive ontology of thought, what might an active ontology of thought - or the proliferation of active ontologies of thought - look like? These questions are all central to Deleuze's affirmative naturalism, the subject of this section.

As with empiricism, to situate Deleuze as a naturalist raises questions about the type of philosophical lineage his naturalism might be associated with. Broadly speaking, varieties of naturalism are often primarily methodological and epistemological, 
rejecting any epistemological primacy to philosophy and subordinating philosophy's 'positing' to the realm of 'empirical scrutiniseability' or to the natural sciences. Through this restriction, such naturalisms often thereby lean on a naturalistic-scientistic ontology. For example, Willard Van Orman Quine's (1969) naturalisation of epistemology involves subordinating epistemology to empirical disciplines such as psychology; Roy Bhaskar's (1998) critical naturalism seeks to naturalise the social sciences and assign philosophy the second-order role of assuming the intelligibility of the (social and natural) sciences, and conceptualise what makes such sciences possible; ${ }^{4}$ and the eliminative materialism of Patricia and Paul Churchland $(1986 ; 1981)$ or Daniel Dennett $(1978 ; 1988)$, for example, who (no doubt, in a Quinean lineage) challenge the ontology of mental states which cannot be explained naturalistically (which, in these cases, means explanations which appeal only to material or extensive relations, or what Deleuze and Guattari call 'referenced chaos' (Deleuze and Guattari 2013b: 206)). Keith Ansell-Pearson and John Protevi helpfully distinguish between different varieties of naturalism pertaining to methodology and ontology, positioning Deleuze (as well as Spinoza and Nietzsche, who will be discussed below) as a weak ontological naturalist, which for them means the denial of 'the existence and explanatory power of supernatural entities, but allows entities and states emergent from and irreducible to the physical (such as organisms), to the biological (such as social institutions), and to the neurological (such as mental states)' (Ansell-Pearson and Protevi 2016: 34). In this paper, I will follow Ansell-Pearson's emphasis on the indissociability of Deleuze's naturalism and worldly practice - therefore emphasising that this position of weak ontological naturalism does not exhaust Deleuze's naturalism - following on from my similar emphasis on the indissociability of Deleuze's empiricism from worldly practice 
in the previous section. Deleuze's own claims to and expressions of naturalism, therefore, as indicated and which I emphasise, do not cohere to this epistemologycentric narrative nor to methodological principles (that is, through something like a commitment to the scientific method). Rather, Deleuze expresses his naturalism through his readings of what he often describes as the 'new' naturalism, though this 'newness' goes back to, at least, Lucretius (and therefore Epicureanism), but also incorporates Leibniz, Spinoza, and Nietzsche, as I already noted. Further, these naturalist gestures consistently entangle the work of philosophy, physics, and, importantly, ethics. Here, I will seek to detach Deleuze's affirmative naturalism from the various gestures he makes towards it through a brief combined discussion of his readings of Lucretius, Spinoza, and Nietzsche for the purposes of developing towards the final section, on Deleuze's empiricist mode of existence.

In his essay 'Lucretius and the Simulacrum', Deleuze extracts from Lucretius a continuous and active ethico-epistemic-philosophical task of demystification when thought is confronted with transcendental signs which tempt thought into reactive mystifications. That is, whenever thought is shocked into being as a result of an encounter. Such transcendental signs can tempt thought into an ascription of infinity to finite compositions, and efface the infinitely distributive and conjunctive productive activity of nature (namely, the productive relations between virtuality, intensity, and actuality). Through Lucretius, Deleuze conceptualises nature as infinite, which is to say as distributive and conjunctive (rather than collective or attributive) through nondeterminable forms; or put more succinctly: nature as ontologically open (Deleuze 2013: 304; Deleuze 2014:394-395). It is of note that the conception of nature developed in this essay is one in which 'nature' is positioned similarly to that of 'difference-in-itself', 
namely, as that by which the given is given (Hayden 1998: 107; Ansell-Pearson and Protevi 2016: 40). In this essay on Lucretius, one of the key discussions pertains to how thought reacts to the encounter and the mechanisms through which psychic stress becomes an effect of thought's relationship to the encounter. In short, despite its differences, Deleuze's essay on Lucretius is one with themes close to those of the Image of Thought from Difference and Repetition discussed above. As I argued above, transcendental empiricism is indissociable from wordly practice, and is bound up with the manner in which we configure our relationships to encounters and make thought an object of practice. This is also the case in affirmative naturalism, as a type of ethics of encounters concerned with the practice of thought. ${ }^{5}$ Deleuze offers different examples of encounters in this essay: simulacra, eidôla (theological phantasms), or the clinamen (the atomic swerve). The speed at which these encounters occur makes them perplexing, disturbing, and unrecognisable, and so, runs the risk of producing 'the mirage of a false infinite in the images which they form' (Deleuze 2013: 314). Deleuze describes these encounters in terms remarkably similar to his description of encounters in Difference and Repetition, insofar as clinamen, for example, cannot be sensed but nonetheless produce sensibility. Encounters with simulacra appear to represent the infinite and thought reactively attributes a false infinity to them due to the speed at which they are encountered; such a reactive attribution, for Lucretius, is not only a mystification but also a cause of psychic suffering and distress (Lucretius 2001: 136). Practically, in such cases, thought reactively synthesises difference rather than actively incorporating it (Ansell-Pearson 2014: 133-134).

As such, the task of naturalism becomes, for Deleuze, about affirming the productive power of nature and the practical project of demystification. Ryan Johnson, 
on this, notes that Deleuze's Lucretian naturalism 'affirms the power of nature to generate everything that is seen, felt and thought' and that this 'project of practical demystification' can be linked with an 'art of organising encounters on an atomic surface of infinite variation' (Johnson, 2014: 85). This is also to say that that practice of demystification is an affirmative practice, and affirmative naturalism, like transcendental empiricism, is immediately concerned with an active practice of thought and learning. Mystifications are, here, treated as ascriptions of false infinity, and as reactive ascriptions of supernaturalist, non-immanent, or quite simply non-naturalist explanatory closure, whereby we can say that thought was 'unprepared' for or was 'unworthy' of the encounter. Importantly, this movement of reactive thought is a danger internal to thought itself, as Michael Bennett notes:

Like Kantian transcendental illusions, Epicurean false infinities are internal to perception-cognition itself [...] Since eidôla are not perceivable as such, one is only aware of perceiving permanent external objects. But the permanency of such objects is, for Epicurus, a function of opinion: we believe we see permanent objects or continuous motion, but we see eidôla. Because of the way perception, cognition and opinion divide their labor, Deleuze says, it is common for the illusions of false infinity to arise. (Bennett 2013: 141)

As a danger internal to thought itself, such reactive or alternatively base thought which such illusions constitute is also what Deleuze describes, through Nietzsche, as stupidity. Stupidity is not to be situated as that which thought can and should escape 'once and for all.' Rather, stupidity - manifestations of which include mystifications, superstitions, dogmatisms, reactive syntheses of difference more generally, ascriptions of final causation, ressentiment, bad conscience, and the ascetic ideal, to name only some 
examples - is a tendential weakness of thought. Just as Lucretian false infinities were internal dangers to thought, stupidity is likewise a 'structure of thought as such' (Deleuze 2002: 105; Bryant, 2008: 133). In other words, stupidity is immanent to thought, and not something that is simply the result of some factor external to thought's operation or which can be completely 'unlearned.' Deleuze goes further than this, however, arguing that stupidity is both a tendential weakness of, but necessary for thought as such; 'thought thinks only when constrained or forced to do so, [it] remains stupid so long as nothing forces it to think [and so it is] the existence of stupidity which forces it to think' (Deleuze 2014: 361, my alteration; also see: Voss 2013: 43-47). If the encounter which forces thought's movement is also a manifestation of thought's tendential stupidity, thought is by no means determined to respond 'reactively.' Indeed, Deleuze identifies with philosophy itself the task of responding actively to thought's tendential stupidity through criticising and overturning its manifestations; philosophy's 'only use is the exposure of all forms of baseness of thought' (Deleuze 2002: 106). Of course, the uncritical ontology of thought - the Image of Thought - we discussed above is in this sense a manifestation of philosophy's own tendential stupidity: 'there exists, of course, a properly philosophical mystification; the dogmatic image of thought' (Deleuze 2002: 106). Stupidity becomes a constant interlocutor for thought's movement, as one of its crucial conditions, but also that which active thought seeks to go beyond.

These distinctions between 'reactive' and 'active' thought are, for Deleuze, immanent criteria which he explicitly connects to the distinctions between 'joyful' and 'sad' relations in Spinoza, and which provides us with a segway into a brief discussion of this third figure of Deleuze's naturalist heritage. Broadly speaking, joyful relations occur when a body encounters another body that it ontologically combines with in a 
favourable relation (ontological empowerment). This composition or combination produces joyful affects, increases a body's power of action (a move towards greater perfection). Sad relations occur when a body encounters another body that it cannot combine with, that it resists or simply reacts to, producing sad affects, freezing or decreasing a body's power of action (a move towards lesser perfection or ontological disempowerment) (Spinoza 1996: 77; Deleuze 1988b: 19; Beistegui 2010: 108-110). The Deleuzo-Spinozan pursuit of joy, here, becomes the pursuit of ontological empowerment through compositionist relations. Manifestations of stupidity, as manifestations of reactive thought, are thereby treated by Deleuze as sad relations, sad thoughts, that is, as ontologically disempowering thought. This explains why Deleuze, with Guattari, identifies arborescent thought (of which the Image of Thought is, no doubt, an example) as a 'sad image of thought' (Deleuze and Guattari 2013a: 16). Sad thought cuts us off from our power of action. Deleuze, by extension, calls the process of forming joyful, compositionist relations with other bodies a 'learning process' which is a body's 'becoming active' (Deleuze 1992: 288); and so, the pursuit of joy becomes a continuous pursuit and practice of learning. It is through this claim that Deleuze can thereby connect Spinoza and Lucretius together in an affirmative naturalism against superstition and sadness:

[Spinoza's is] a naturalist philosophy. Superstition is everything that keeps us cut off from our power of action and continually diminishes it. The source of superstition is thus the concatenation of sad passions, fear, the hope linked to fear, the anxiety that delivers us over to phantoms. Spinoza knew, like Lucretius, that there are no joyful myths or superstitions [...] And like Lucretius again, Spinoza assigns to philosophy the task of denouncing all that is sad, all that lives 
on sadness, all those who depend on sadness as the basis of their power. (Deleuze 1992: 270, my alteration)

Let me now weave together some of the threads I have been developing here before moving onto our final section. I have, admittedly briefly, surveyed Deleuze's treatment of three of the key figures in what he often terms the 'new' naturalism, a naturalism whose object is a continuous practice of demystification or as a struggle against thought's tendential stupidity. Whereas in Lucretius this was focused on naturalism as an affirmative practice of demystification, in Nietzsche this transformed into a struggle against thought's base tendencies more generally (namely, stupidity), and in Spinoza against sad passions and sad relations which cut us off from our power of action. The type of practice, philosophy of life, or aesthetics of existence practice that Deleuze's naturalism pushes us towards is, I argue, one in the pursuit of learning, joy, and ontological empowerment. Ansell-Pearson underlines this with clarity:

Deleuze is, then, first and foremost, an ethically motivated naturalist: he attaches himself to naturalism because he sees it as a project of demystification and human emancipation. The task is to liberate human beings from the realm of myth: the myth of religion, the myth of a false physics, and the myths of a false philosophy. This naturalism consists in the critique of superstition since it is this that cuts us off from our power of action and diminishes it, and induces in us sadness: naturalism exists, says Deleuze, to defeat this sadness. (Ansell-Pearson 2016: 131)

As does Patrick Hayden: 
The speculative and practical objects of naturalism coincide on this point: the enterprise of demystification through philosophical, scientific, and ethical activity intended to free humans from the illusions of onto-theological transcendence. (Hayden 1997: 189)

I will now move onto to this paper's final substantive section, where I will elucidate in some more detail how I seek to combine the two approaches we have discussed so far in what I am calling an empiricist mode of existence.

\section{An Empiricist Mode of Existence}

As I noted above, stupidity is an immanent tendency of thought, a reactive danger which thought must always contend with. Stupidity cannot simply be overcome through its 'diagnosis,' nor 'cured,' as Anna Cutler and Iain MacKenzie point out, 'with a dose of knowledge' (Cutler and MacKenzie 2011: 8). Further, in both sections, my discussions culminated with a gesture towards learning as both what transcendental empiricism pushes us towards in terms of a praxis of learning (which was preliminarily defined in terms of 'ontological experimentalism' and 'epistemological openness'), and what affirmative naturalism pushes us towards in terms of a continuous pursuit of joy or ontological empowerment. In this section, I seek to articulate the combinative intersection of these two vectors in Deleuze's thought as a worldly practice I call an empiricist mode of existence. This term is extracted from the following claim by Deleuze and Guattari in What is Philosophy?, in which they begin to develop a 'mode of existence' with immanent criteria (of which joy/sadness is our main example in this paper) flowing from what they call an 'empiricist conversion': 
A mode of existence is good or bad, noble or vulgar, complete or empty, independently of Good and Evil or any transcendent value: there are never any criteria other than the tenor of existence, the intensification of life [...] It may be that believing in this world, in this life, becomes our most difficult task, or the task of a mode of existence still to be discovered on our plane of immanence today. This is the empiricist conversion. (Deleuze and Guattari 2013b: 74-75, my emphasis, also see Rölli, 2016: 131-132)

Rölli likewise describes this in terms of an 'ethics of intensity' concerned with 'discovering ways of subjectivising on the plane of immanence' (Rölli 2016: 279). Of course, no mode existence can function as a guarantee against thought's tendential stupidity. And indeed, any mode of existence which seeks to grapple with and overturn thought's reactive tendencies in a pursuit of joy or ontological empowerment will pass through the crucial question of sustainability. In this section, I will first broadly introduce what an empiricist mode of existence might look like. This will flow into, secondly, a discussion of the questions of sustainability, caution, as well as the important distinction between joy and pleasure.

In his book-length study of Deleuze's transcendental empiricism, Bryant concludes with a formulation of Deleuze's transcendental empiricism as an experimental philosophy of life, which is worth quoting at length:

[I]f this must be called an empiricism, if we must nonetheless affirm empiricism, then this is because we are subjects. Since the transcendental is no longer to be traced from the outlines of the empirical, we can no longer rely on the being of a transcendental constituting subjectivity to bring us before the transcendental, but must instead seek out those gaps, events, traumas, shocks and encounters which upset the smooth continuity of the subject, call its recognition into question, 
and introduce it to a domain that is neither that of the subject nor of the object. If these encounters, these curses, are signs of the transcendental, then this is because they announce a difference that is no longer that of the external or material, but something unspeakable [...] [T] hese encounters are nonetheless encounters, and for that reason the transcendental philosophy of difference must still be an empiricism. As Deleuze says, we cannot anticipate the outcome of research in advance. (Bryant 2008: 266, second emphasis mine)

Seeking out those 'gaps, events, traumas, shocks and encounters which upset the smooth continuity of the subject' becomes the decidedly ontologically experimentalist task of an empiricist mode of existence. Such a mode of existence is also suffused with an epistemological openness insofar as it embeds in it a struggle against thought's tendential stupidity (learning through demystification), as well as an openness to those learning practices which emerge through (active) differential actualisations of thought (learning through differential movements of thought). As Rölli highlights, such openness - that is, a 'greater capability to allow oneself to be affected' (Rölli 2016: 280) - stimulates thought 'to pursue the various and complex virtual relations' (Ibid. 280). And as I have already noted a number of times, such a task is not isolated, but is rather a continuous praxis: 'learning is, after all, an infinite task' (Deleuze 2014: 215; also see Hardt 1993: 118). It is what Deleuze refers to, with Foucault, as a 'way', which is also to say as an in principle incomplete task (Deleuze 1995: 114-115), ${ }^{7}$ and what Kathrin Thiele associates with open-ended philosophical practice as such (Thiele 2016: 130). The 'content' of an empiricist mode of existence - or empiricist processes of individuation - is decidedly heterogeneous (a process of heterogenesis) which involves giving 'birth to new modes of existence' (Deleuze and Guattari 2013b: 74). However, as I noted above, the very involuntariness (or passivity) through which thought is shocked into being seems to 
conflict with this notion of a 'mode of existence' or 'art of life' which attempts to think actively when confronted with the encounter or transcendental sign. I will respond to this conflict, first, through situating such a mode of existence as an 'endowment' for transcendental signs; second, through underlining the importance of endurance and sustainability to our mode of existence's pursuit of joy, which involves a distinction between joy and pleasure.

The notion of 'endowment' is highlighted by Deleuze in Proust and Signs when he notes: 'one must be endowed for the signs, ready to encounter them, one must open oneself to their violence' (Deleuze 2000: 101). ${ }^{8}$ Transcendental signs, as encounters which force thought into being, demand a response. Of course, Deleuze offers no complete pre-constituted 'method' which might be able to 'equip' us with such an endowment. Indeed, were he to do so, he would, of course, be guilty of generating a new mystification or dogmatism which transcendentalised his empirical experiences. Indeed, this is one of the reasons we must tread carefully when explicating what a empiricist mode of existence might look like, in order to avoid such processes of transcendentalisation in our own explication. Nonetheless, Deleuze and Guattari give us a clue through invoking what they call the 'empiricist conversion,' which I noted above. The empiricist conversion serves as a broad example of what an endowment for signs might look like, and involves the combination of empiricism and affirmation; or put differently, the empiricist conversion as a movement in thought away from the dogmatic Image of Thought and from transcendent modes of thought generally speaking, and an affirmation of the project of demystification (a double movement towards ontological experimentalism and epistemological openness). This coupling of empiricism and affirmation gestures strongly towards the linkages between 
transcendental empiricism and affirmative naturalism, indeed we can also speak of it as a 'naturalist conversion.' With Spinoza, Deleuze will claim that 'ethical joy is the correlate of speculative affirmation' (Deleuze 1988b: 29). Deleuze, in Expressionism in Philosophy, gestures explicitly towards this type of joy-oriented empiricist-naturalist practice:

A man [sic] who is to become reasonable, strong and free, begins by doing all in his power to experience joyful passions. He then strives to extricate himself from chance encounters and the concatenation of sad passions, to organize good encounters, combine his relation with relations that combine directly with it, unite with that which agrees in nature with him, and form a reasonable association between men; all of this in such a way as to be affected with joy. [This is an] art of organizing encounters. (Deleuze 1992: 262, my alteration, my emphasis)

What this indicates, again, but importantly, is that this empiricist-naturalist 'conversion' is by no means reducible to extensive space-time co-ordinates or to a particular empirical experience, but rather implies a durative process, practice, or project of conversion. Such a conversion is a processual and transformative practice, and certainly not an epistemological judgement or decision; all of this is also to say that the process of becoming-empiricist or becoming-naturalist is never completed once and for all. Insofar as this empiricist mode of existence seeks to confront thought's tendential stupidity, and insofar as stupidity is never overcome once and for all, then to surmise that one has 'completed' this conversion or that one has 'overcome' stupidity would be, no doubt, in these terms, profoundly stupid. Thiele notes this well, underlining the demandingness, endurance, and sustainability required by such a task: 
'To believe in the world, as it is', as a thought of pure immanence, does not mean producing an affirmation of the world according to the ideality of 'what should be' - measuring the possible via the criterion of 'what is', and thus limiting this world from the very start. No, what is truly required is to produce an active affirmation in the face of every single result the world ever takes. Only this way is the becoming-active in and for this world truly never ending; only this way is it an infinite task, in which mere affirmation of chance becomes active affirmation, and belief in this world - still harbouring the comfort of the transcendent (divine providence, revolutionary axiomatic or a saving messianism) - becomes a 'belief in this world, as it is'. It is the most demanding realist undertaking that alone leaves open 'what the world is capable of. (Thiele 2010: 35-36; also see Thiele 2008: 182)

An immanent engagement in the world is what Thiele calls for through an empiricist mode of existence. An 'empirical practice of the faculties' heightening 'one's capacity to be affected while expanding and enhancing the experiential reserves one can draw upon', generating 'new singularities in thought' (Rölli 2016: 284-285). This, by extension, associates transcendent approaches with non-immanent disengagement from the world, or more simply, indifference (MacKenzie 2004). (I will revisit this point in the conclusion as we gesture towards further avenues of research.) Such an immanent engagement functions as a continuous commitment to active thought, speculative practice, or that which Aline Wiame notes in relation to Deleuze's notion of dramatisation as an 'ontology of creation, as it is the selection that makes new, affirmative configurations possible' (Wiame 2016: 45).

Focusing more closely on the above quote from Thiele: the invocation, here, of the centrality of endurance and sustainability to an empiricist mode of existence 
functions not only to centralise the durative and processual nature of such a practice, but also to decouple the potential link that might be drawn between Deleuze's Spinozist notion of joy being employed (as ontological empowerment) and pleasure. To what extent is this empiricist-naturalist conversion - a conversion involving ontologically experimentalist and epistemologically open practices which functions as an 'endowment' for transcendental signs - a 'joyful' practice, especially insofar as the encounter is violent, traumatic, and disturbing? I cannot come to a totalising response to this question, but it will be important for my purposes to note a crucial distinction between joy and pleasure. The concept of joy being deployed here is ontological and non-anthropocentric (not tied to the subject), whereas pleasure is an anthropocentric notion (tied to the subject). Ontological joy is not reducible to anthropocentric pleasure. Joy is, simply, the increase in a body's power of action brought about through entering compositionist relations. It is an affective, relational and ontological movement. As Protevi notes, for Deleuze (and Guattari), feelings such as pleasure are the 'subjective appropriation of a desubjectivizing joyous affect' (Protevi 2013: 74-75). That is: 'pleasure [...] interrupts the continuous process of positive desire [...] pleasures, even the most artificial, are reterritorializations' (Deleuze and Guattari 2013b: 180-181). What this means is not that pleasure has nothing to do with joy, but rather than pleasure is an arrest in the movement of joy and is thereby not reducible to it. Subjectified feelings of pleasure may be either joyful (ontologically empowering) or sad (ontologically disempowering). To give an example of the latter: processes of capitalist reterritorialisation insinuate lack and capture desire through continuous (pleasurable) consumption or through continuous (pleasurable) production in which the 'consumer' or 'worker' is affective invested in his or her contributions to capital accumulation, and 
often simultaneously to his or her own exploitation (Deleuze and Guattari 1984; Lazzarato 1996; Holland 1999: 79; Lordon 2014). The types of pleasures produced under capitalism, in this specific sense, are ontologically sad. Relatedly, joyous movements may be coupled with subjectified moments of sadness, pain, or even hatred. On the example of 'joyous hate,' we can gesture towards Deleuze when, praising Foucault's work, he speculates that joyous hatred is an explanation for Foucault's intense research and style: 'provided the hatred is strong enough something can be salvaged, a great joy which is not the ambivalent joy of hatred, but the joy of wanting to destroy whatever mutilates life' (Deleuze 1988a: 23). On the example of sadness and pain: Rosi Braidotti, on this, warns us that such an empiricist mode of existence (a term she does not use), as a process which demands endurance and sustainability, is by no means necessarily harmonious. Insofar as such endurance involves traumatic encounters it will involve conflicts and shocks, and so, commitment to such a mode of existence will involve the negotiation between an openness to the potential trauma of the encounter and a relative level of caution so as to avoid breakdown and produce a sustainable mode of existence (Braidotti 2006: 139). This rule of caution folds into our empiricist mode of existence the importance of sustainability and the acknowledgement that the pursuit of joy is in no sense the pursuit of pleasure. ${ }^{9}$ Deleuze and Guattari repeatedly highlight the necessity of such a cautionary rule, here we take only one of many examples to conclude this section:

Every undertaking of destratification (for example, going beyond the organism, plunging into a becoming) must therefore observe concrete rules of extreme caution: a too-sudden destratification may be suicidal, or turn cancerous. In other words, it will sometimes end in chaos, the void and destruction, and 
sometimes lock us back into the strata, which become more rigid still, losing their degrees of diversity, differentiation, and mobility. (Deleuze and Guattari 2013b: 585)

In this section I have extracted an empiricist mode of existence as a stylistics of life which is ontologically experimentalist, epistemologically open, and immanently engaged in the world: a joyful continuous praxis of demystification, creative thought; that is, of learning.

\section{Conclusion}

In this paper I have endeavoured to co-position Deleuze's (transcendental) empiricism and (affirmative) naturalism as being indissociable from worldly practice of learning, and as pertaining to a stylistics of life which is ontologically experimentalist, epistemologically open, and immanently engaged in the world towards joy. The central purpose of this paper has been to develop on these two under-researched areas of Deleuze's thought and to emphasise that neither Deleuzian empiricism nor Deleuzian naturalism can be properly considered as solely pertaining to epistemology, methodology, or philosophical practice. Or, to put this another way, Deleuzian empiricism and Deleuzian naturalism cannot be reduced to a 'position' that Deleuze 'held', as both are concerned with ontologically transformative worldly practice.

In the introduction, I noted that I hope that this research can help generate new problems worthy of further exploration. The potential vectors are numerous: what might an empiricist mode of epistemology, pedagogy, aesthetics, or politics look like, for example? Conceived of in relation to the 'ethics of self-cultivation' literature, how might Deleuze's contribution engage with these discussions? With posthumanism 
(Braidotti 2013)? Or with Bergsonian philosophy of life more generally (Bergson 1944;

Deleuze 1991; Ansell-Pearson 2015)? Linking this practical critique of mystification and differential processes of learning with Deleuze's development of counter-actualisation and dramatisation is a further vector worthy of independent consideration, bearing as it does the potential coupling of these two notions in a mode of existence which, as Janae Sholtz notes, is a coupling which is unfortunately rarely discussed in the literature (Sholtz 2016). Finally, I claimed that this empiricist mode of existence is a practice which is immanently effectuated, which is to say, is a participation in rather than indifference from the world. MacKenzie makes similar claims with regard the practice of critique as such, as a practice involved in the creative construction of difference and the combat of indifference. As such, a further vector of research might be a substantive engagement between the practice of pure critique, as MacKenzie terms it, and the pursuit of joy which I have developed here.

\section{Notes}

\footnotetext{
${ }^{1}$ Not that these different empiricisms can be conflated. Further, and of course, Deleuze finds much in Hume's empiricism that informs his own approach, not least the notion of 'knowledge' as a sort of 'habit' and the externality of relations to their terms, as only two examples.

${ }^{2}$ See Dillet's paper, further, for an interesting exploration of Deleuze's Heideggerian inheritance in this notion of the encounter.

${ }^{3}$ On this, see: Baugh (1992), Ansell-Pearson (1999), Protevi (2013), and Clisby (2015).

${ }^{4}$ A third example which we will not discuss here but nonetheless should be mentioned is Ray Brassier's recent work on the naturalism of Wilfrid Sellars, which attempts to grabble with the 'myth of the given.' See Brassier (2014).

${ }^{5}$ Here, therefore, it is unsurprising that Paul Patton argues that Deleuze's positions are incompatible with 'thoroughgoing scientific [naturalism]' (Patton 2016: 348) insofar as the definition of naturalism Deleuze is measured against is one in which one must have a 'commitment to a scientific conception of the world and to scientific method as the only reliable path to knowledge' (Patton 2016:348), or be committed to the 'modern scientific image of the world as a single, closed causally interconnected system' (Patton 2016: 352). Deleuze, it would seem, is uncontroversially not a naturalist in this sense. I agree both with this general claim by Patton, as well as his suggestions on the practico-ethical component of Deleuze's naturalism towards the end of his paper, while nonetheless taking more seriously than Patton perhaps does that Deleuze's claims of the ontological openness of nature should be taken more seriously as a naturalist claim.

${ }^{6}$ The notion of a 'mode of existence' being deployed here is therefore drawn from this excerpt from What is Philosophy?, and is not in reference to the recent work of Bruno Latour (2013). Indeed, a discussion
} 
connecting Deleuze and Guattari's usage of this term to Latour would certainly be an interesting and potentially fruitful endeavour which would, no doubt, necessitate passing through Gilbert Simondon's own usage of the term in On the Mode of Existence of Technical Objects (2012). This is, however, beyond the scope of this paper. I thank one of the peer reviewers for highlighting this potential connection to Latour.

${ }^{7}$ This notion of an being incomplete in principle is drawn from Ian Buchanan's (2013: 163-164) work on schizoanalysis.

${ }^{8}$ Of course, this notion of 'endowment' is bound up with the notion of 'apprenticeship', though we will not be discussing the latter notion here.

${ }^{9}$ We can add a caveat to this claim. In 'Lucretius and the Simulacrum', Deleuze discusses the notion of Lucretian pleasure more affirmatively than he engages with the notion elsewhere. No doubt, Lucretian or Epicurean pleasure is distinct from, for example, capitalist pleasure. This opens the question of whether Lucretius's notion of pleasure, which is that of a sort of mental contentedness free from psychological anxiety wrought by superstitions and the fear of death, could be made compatible with Deleuze's desubjectified use of joy. I will not explore this here, but see Ansell-Pearson (2016) for a related discussion in which the notion of Epicurean pleasure is linked to Deleuze in more detail.

\section{References}

Abdullah, Ayesha (2016), 'The Birth of Thought: Dramatization, Pluralisation and the Idea', Deleuze

Studies, 10: 1, pp. 19-32

Ansell-Pearson, Keith (1999), Germinal Life: The Difference and Repetition of Deleuze, London: Routledge Ansell-Pearson, Keith (2014), 'Affirmative Naturalism: Deleuze and Epicureanism', Cosmos and History: The Journal of Natural and Social Philosophy, 10: 2, pp. 121-137

Ansell-Pearson, Keith (2015), 'Beyond the Human Condition: Bergson and Deleuze', in Deleuze and the Non/Human, ed. by Jon Roffe and Hannah Stark, London: Palgrave Macmillan, pp. 81-102

Ansell-Pearson, Keith (2016), 'Naturalism as a Joyful Science: Nietzsche, Deleuze, and the Art of Life', Journal of Nietzsche Studies, 47: 1, pp. 119-140

Ansell-Pearson, Keith and Protevi, John (2016), 'Naturalism in the Continental Tradition', in The Blackwell Companion to Naturalism, ed. by Kelly James Clark, West Sussex: Wiley Blackwell, pp. 34-48

Baugh, Bruce (1992), 'Transcendental Empiricism: Deleuze's Response to Hegel', Man and World, 25, pp. 133-148

Beistegui, Miguel de (2010), Immanence: Deleuze and Philosophy, Edinburgh: Edinburgh University Press Bennett, Michael James (2013), 'Deleuze and Epicurean Philosophy: Atomic Speed and Swerve Speed', Journal of French and Francophone Philosophy, XXI: 2, pp. 131- 157

Bergson, Henri (1944), Creative Evolution, trans. by Arthur Mitchell, Connecticut: Greenwood Press Bhaskar, Roy (1998), The Possibility of Naturalism: A Philosophical Critique of the Contemporary Human Sciences, Routledge: London

Braidotti, Rosi (2006), 'The Ethics of Becoming-Imperceptible', in Deleuze and Philosophy, ed. by Constantin V. Boundas, Edinburgh: Edinburgh University Press, pp. 133-159

Braidotti, Rosi (2013), The Posthuman, Cambridge: Polity

Brassier, Ray (2014), 'Nominalism, Naturalism, and Materialism: Sellars's Critical Ontology', in Contemporary Philosophical Naturalism and its Implications, ed. by Bana Bashour and Hans D. Muller, London: Routledge, pp. 101-114

Bryant, Levi R. (2008), Difference and Givenness: Deleuze's Transcendental Empiricism and the Ontology of Immanence, Evanston: Northwestern University Press

Buchanan, Ian (2013), 'Schizoanalysis: An Incomplete Project' in The Edinburgh Companion to Poststructuralism, ed. by Benoît Dillet, Iain MacKenzie and Robert Porter, Robert, Edinburgh: Edinburgh University Press, pp. 163-88

Churchland, Patricia Smith (1986), Neurophilosophy: Toward a Unified Science of the Mind/Brain, Cambridge, MIT Press

Churchland, Paul (1981), 'Eliminative Materialism and the Propositional Attitudes', Journal of Philosophy, 78, pp. 67-90

Clisby, Dale (2015), 'Deleuze's Secret Dualism? Competing Accounts of the Relationship Between the Virtual and the Actual', Parrhesia, 24, pp. 127-149 
Cutler, Anna and MacKenzie, Iain (2011), 'Critique as a Practice of Learning: Beyond Indifference with Meillassoux, towards Deleuze', Pli: The Warwick Journal of Philosophy, 22, pp. 88-109

Deleuze, Gilles (1988a), Foucault, trans. by Seán Hand, Minneapolis: University of Minnesota Press Deleuze, Gilles (1988b), Spinoza: Practical Philosophy, trans. by Robert Hurley, San Francisco: City Lights Books

Deleuze, Gilles (1991a), Bergsonism, trans. by Hugh Tomlison and Barbara Habberjam, Brooklyn: Zone Deleuze, Gilles (1991b), Empiricism E Subjectivity: An Essay on Hume's Theory of Human Nature, trans. by Constantin V. Boundas, New York: Columbia University Press

Deleuze, Gilles (1992), Expressionism in Philosophy: Spinoza, trans. by Martin Joughin, New York: Zone Books

Deleuze, Gilles (1995), Negotiations: 1972-1990, trans. by Martin Joughin, New York: Columbia University Press

Deleuze, Gilles (1999), 'Bergson's Conception of Difference', in The New Bergson, ed. by John Mullarkey, trans. by Melissa McMahon, Manchester: Manchester University Press, pp. 42-65

Deleuze, Gilles (200o), Proust and Signs, trans. by Richard Howard, Minneapolis: University of Minnesota Press

Deleuze, Gilles (2001), Pure Immanence: Essays on a Life, trans. Anne Boyman, New York: Zone Books

Deleuze, Gilles (2002), Nietzsche and Philosophy, trans. by Hugh Tomlinson, London: Continuum

Deleuze, Gilles (2013), The Logic of Sense, trans. by Mark Lester and Charles Stivale, London: Bloomsbury Deleuze, Gilles (2014) Difference and Repetition, trans. by Paul Patton, London: Bloomsbury Academic Deleuze, Gilles (2015), What is Grounding?, trans. by Arjen Kleinherenbrink, Grand Rapids: \&\&\& Publishing

Deleuze, Gilles and Guattari, Félix (1984), Anti-Oedipus: Capitalism and Schizophrenia, trans. by Robert Hurley, Mark Seem and Helen R. Lane, London: The Athlone Press

Deleuze, Gilles and Guattari, Félix (2013a), A Thousand Plateaus: Capitalism and Schizophrenia, trans. by Brian Massumi, London: Bloomsbury Academic

Deleuze, Gilles and Guattari, Félix (2013b), What is Philosophy? trans. by Hugh Tomlinsin and Graham Burchill, London: Verso

Dennett, Daniel (1978), 'Why You Can't Make a Computer that Feels Pain', Synthese, 38: 3, pp. 415-456

Dennett, Daniel (1988), 'Quining Qualia' in Consciousness in Contemporary Science, ed. by Marcel, A. J. and Bisiach, E,, New York: Oxford University Press, pp. 42-77

Dillet, Benoît (2013), 'What Is Called Thinking?: When Deleuze Walks along Heideggerian Paths', Deleuze Studies, 7: 2, pp. 230-274

Hardt, Michael (1993), An Apprenticeship in Philosophy: Gilles Deleuze, London: UCL Press

Hayden, Patrick (1997), 'Gilles Deleuze and Naturalism: A Convergence with Ecological Theory and Politics', Environmental Ethics, 19: 1, pp. 185-204

Hayden, Patrick (1998), Multiplicity and Becoming: The Pluralist Empiricism of Gilles Deleuze, New York: Peter Lang

Holland, Eugene (1999), Deleuze and Guattari's Anti-Oedipus: An Introduction to Schizoanalysis, London: Routledge

Johnson, Ryan J. (2014), 'Another Use of the Concept of the Simulacrum: Deleuze, Lucretius, and the Practical Critique of Demystification', Deleuze Studies, 8: 1, pp. 70-93

Latour, Bruno (2013), An Inquiry into Modes of Existence: An Anthropology of the Moderns, trans. by Catherine Porter, Cambridge, MA: Harvard University Press

Lazzarato, Maurizio (1996), 'Immaterial Labour', in Radical Thought in Italy: A Potential Politics, ed. by Paul Virno and Michael Hardt, trans. by Paul Colilli and Ed Emory, Minneapolis: University of Minnesota Press, pp. 133-147

Lordon, Frédéric (2014), Willing Slaves of Capital: Spinoza and Marx on Desire, trans. by Gabriel Ash, London: Verso

Lucretius (2001), On the Nature of Things, trans. by Martin Ferguson Smith, Indianapolis: Hackett

MacKenzie, Iain (2004), The Idea of Pure Critique, London: Continuum

Patton, Paul (2016), 'Deleuze and Naturalism', International Journal of Philosophical Studies, 24: 3, pp. 348-364

Protevi, John (2013), Life, War, Earth: Deleuze and the Sciences, Minneapolis: University of Minnesota Press

Quine, Willard Van Orman (1969), 'Epistemology Naturalized', in Ontological Relativity and Other Essays, New York: Columbia University Press, pp. 69-90 
Posteraro, Tano S. (2016), 'Do Not Just Do As I Do: Knowledge and Learning in the Image of Thought', Deleuze Studies, 9: 4, pp. 455-474

Rajchmann, John (2010), The Deleuze Connections, Cambridge: The MIT Press

Rölli, Marc (2016), Gilles Deleuze's Transcendental Empiricism: From Tradition to Difference, trans. by Peter Hertz-Ohmes, Edinburgh: Edinburgh University Press

Sholtz, Janae (2016), 'Dramatization as Life Practice: Counteractualisation, Event and Death', Deleuze Studies, 10: 1, pp. 50-69

Smith, Daniel W. (2012), Essays on Deleuze, Edinburgh: Edinburgh University Press

Simondon, Gilbert (2009), 'The Position of the Problem of Ontogenesis', Parrhesia, 7, pp. 4-16

Simondon, Gilbert (2012), Du Mode d'existence des Objets Techniques, Paris: Aubier

Spinoza, Benedict de (1996), Ethics, trans. by Edwin Curley, London: Penguin Books

Thiele, Kathrin (2008), The Thought of Becoming: Gilles Deleuze's Poetics of Life, Zürich-Berlin: diaphanes Thiele, Kathrin (2010), 'To Believe In This World, As It Is': Immanence and the Quest for Political Activism', Deleuze Studies, 4, pp. 28-45

Thiele, Kathrin (2016), 'Of Immanence and Becoming: Deleuze and Guattari's Philosophy and/as Relational Ontology', Deleuze Studies, 10: 1, pp. 117-134

Voss, Daniela (2013), Conditions of Thought: Deleuze and Transcendental Ideas, Edinburgh: Edinburgh University Press

Wiame, Aline (2016), 'A Thought Without Puppeteer: Ethics of Dramatization and Selection of Becomings', Deleuze Studies, 10: 1, pp. 33-49

Williams, James (2010) 'Levi R. Bryant, Difference and Givenness: Deleuze's Transcendental Empiricism and the Ontology of Immanence', Parrhesia, 9, 115-119

Williams, James (2016), A Process Philosophy of Signs, Edinburgh: Edinburgh University Press 